\title{
To find out the suitable high yielding varieties of lentil for rainfed conditions of eastern Uttar Pradesh
}

\author{
AKHILESH CHANDRA YADAV*, O.P. RAI, SAMAR PAL SINGH, H.C. YADAV, R.K. YADAV AND \\ NAVNEET KUMAR \\ Department of Agronomy, Narendra Dev University of Agriculture and Technology, Kumarganj, FAIZABAD (U.P.) \\ INDIA \\ (Email : akhileshyadav1407@gmail.com)
}

\begin{abstract}
The field experiment was conducted at Agronomy Research Farm of N.D.U.A. and T., Kumarganj, Faizabad during Rabi season of 2013-14 to study the performance of lentil varieties under rainfed condition in respect of growth and development, yield and yield contributing characters, quality and economics. Twelve varieties of lentil IPL-81, K-75, NDL-1, IPL-406, DPL-15, PL-5, PL-234, PL-4, DPL-62, PL-406, PL-63 and HUL-57 were tested in Randomized Block Design (RBD) with three replications. The soil of the experimental field was silty loam in texture, having $\mathrm{pH} 8.3$, organic carbon 0.35 per cent, available nitrogen $175 \mathrm{~kg} \mathrm{ha}^{-1}$, phosphorus $14.50 \mathrm{~kg} \mathrm{ha}^{-1}$, potassium $248.50 \mathrm{~kg} \mathrm{ha}^{-1}$ and electrical conductivity $0.41 \mathrm{dSm}^{-1}$. The performance of PL-406 variety of lentil was found significantly superior over rest of the varieties in respect of all growth, yield and yield contributing characters except plant height and test weight. The maximum plant height was recorded in IPL-406 variety while the higher test weight (g) was recorded in DPL-62 variety. The highest net return (Rs. $73743 \mathrm{ha}^{-1}$ ) and B:C ratio (4.3) was obtained with PL-406 variety of lentil under the rainfed condition.
\end{abstract}

Key Words : Yield, Growth, High yielding varieties, Rainfed

View Point Article : Yadav, Akhilesh Chandra, Rai, O.P., Singh, Samar Pal, Yadav, H.C., Yadav, R.K. and Kumar, Navneet (2016). To find out the suitable high yielding varieties of lentil for rainfed conditions of eastern Uttar Pradesh. Internat. J. agric. Sci., 12 (2) : 279-282, DOI:10.15740/ HAS/IJAS/12.2/279-282.

Article History : Received : 02.02.2016; Revised : 10.03.2016; Accepted : 03.05.2016 